\title{
Retraction \\ Retraction: Constantin et al. Animal Models in Bladder Cancer. Biomedicines 2021, 9, 1762
}

\author{
Traian Constantin 1,2,+(D), Mihai Păvălean 1,3,*,+, Ștefana Bucur 1,4,*,+, Maria Magdalena Constantin 1,4,+(D), \\ Alin Codrut Nicolescu $1,5,+\mathbb{D}$, Irina Pacu ${ }^{1,6,+} \mathbb{D}$ and Victor Mădan $1,3,+$
}

Citation: Constantin, T.; Păvălean,

M.; Bucur, Ș.; Constantin, M.M.;

Nicolescu, A.C.; Pacu, I.; Mădan, V.

Retraction: Constantin et al. Animal

Models in Bladder Cancer.

Biomedicines 2021, 9, 1762

Biomedicines 2022, 10, 110. https://

doi.org/10.3390/biomedicines

10010110

Received: 28 December 2021

Accepted: 29 December 2021

Published: 6 January 2022

Publisher's Note: MDPI stays neutral with regard to jurisdictional claims in published maps and institutional affiliations.

Copyright: (C) 2022 by the authors. Licensee MDPI, Basel, Switzerland. This article is an open access article distributed under the terms and conditions of the Creative Commons Attribution (CC BY) license (https:// creativecommons.org/licenses/by/ $4.0 /)$.
1 Faculty of Medicine, "Carol Davila” University of Medicine and Pharmacy, 050474 Bucharest, Romania; traianc29@yahoo.com (T.C.); drmagdadinu@yahoo.com (M.M.C.); nicolescualin66@yahoo.com (A.C.N.); irinapacu@hotmail.com (I.P.); victmad@gmail.com (V.M.)

2 Department of Urology, "Prof. Dr. Th. Burghele" Hospital, 050652 Bucharest, Romania

3 Department of Urology, Emergency University Central Military Hospital, 010825 Bucharest, Romania

Ind Department of Dermatology, Colentina Clinical Hospital, 020125 Bucharest, Romania

5 Roma Medical Center for Diagnosis and Treatment, 011773 Bucharest, Romania

6 Department of Gynecology, "Sfântul Pantelimon" Emergency Hospital, 021659 Bucharest, Romania

* Correspondence: pavaleanmihai21@gmail.com (M.P.); stefanabucur11@gmail.com (S.B.)

$+\quad$ All authors had equal contribution.

The journal retracts the article, "Animal Models in Bladder Cancer. Biomedicines 2021, 9, 1762" [1]. Following publication, concerns were brought to the attention of the publisher regarding a significant overlap with a previously published article Insights from "Animal Models of Bladder Cancer: Recent Advances, Challenges, and Opportunities Oncotarget 2017, 8, 57766-57781" [2].

Adhering to our complaint procedure, an investigation was conducted, which revealed an unacceptably high level of similarity between this manuscript and the previously mentioned publication. As a result, this article is retracted.

This retraction was approved by the Editor in Chief of the journal Biomedicines.

The authors agreed to this retraction.

\section{References}

1. Constantin, T.; Păvălean, M.; Bucur, Ș.; Constantin, M.M.; Nicolescu, A.C.; Pacu, I.; Mădan, V. Animal Models in Bladder Cancer. Biomedicines 2021, 9, 1762. [CrossRef]

2. John, B.A.; Said, N. Insights from animal models of bladder cancer: Recent advances, challenges, and opportunities. Oncotarget 2017, 8, 57766-57781. 